\title{
Паренхімозберігаюча стратегія при метастатичному ураженні печінки: когортне проспективне дослідження
}

\author{
Національний інститут раку, Київ \\ Одержано: 6.07.2020 \\ Прийнято до друку: 21.07.2020 \\ DOI: $10.32471 /$ clinicaloncology.2663-466X.37-1.27049
}

\begin{abstract}
Актуальність. Дискусія щодо доцільності виконання широкого відступу від краю пухлинного вогнища при резекціях печінки у пацієнтів з метастазами колоректального раку (мКРР) триває майже 20 років. Дотепер маловивченими залишаються результати паренхімозберігаючої стратегії при локалізації метастатичних утворень у важкодоступних сайтах печінки з точки зору хірургічної анатомії органа (переважно праве “венозне ядро", портальні та кавальні “ворота" печінки, паракавальна частина першого сегменту). Матеріали та методи. Виконано проспективне одноцентрове дослідження (січень 2015 р. липень 2020 р.) 3 включенням 185 хворих на мКРP (рT1-4N0-2M0-1). Залежно від локалізації метастатичних вогнищ мКРP хворих було розподілено на 2 групи порівняння. До першої групи ( $n=107)$ віднесли пацієнтів з периферично локалізованими метастазами (ПЛМ), у паренхімі лівої латеральної секції (S2, S3), задньої секції (S6, S7), Спігелієвій частці S1 та субкапсульно на глибині 1-2 см. До другої групи ( $n=78$ ) віднесли хворих з ураженням центральних сайтів печінки (ЦСП) , метастатичні вогнища в яких локалізовані переважно в межах «правого венозного ядра" печінки, портальних та кавальних воріт, паракавальної та каудальної частини S1, в глибоких сайтах S4, S5, S8. Результати. Післяопераційні тяжкі ускладнення зареєстровано у $19(24,4 \%)$ та 17 (21,8\%) хворих відповідно для груп порівняння (ЦСП та ПЛМ), р=0,15. Не було зареєстровано відмінностей у групах за рівнем гепатоспецифічних ускладнень, що становили 8,9\% та 4,6\% для цСП та ПлМ відповідно $(p=0,3)$. Була зареєстрована статистична відмінність за рівнем 3-річної безрецидивної виживаності у досліджуваних групах хворих та становила 63 та 41\% відповідно для групи ЦСП та ПЛМ (p=0,008). Кумулятивна безрецидивна 3-річна виживаність для когорт R0 та R1v хворих групи ЦСП становила 43 та 33\% відповідно (p=0,44). Висновки. Адаптація паренхімозберігаючої хірургічної стратегії у хворих із метастатичним ураженням важкодоступних сайтів печінки забезпечила референтну 3-річну виживаність, відповідно до світового досвіду. Стратегія R1v у поєднанні із сучасними схемами поліхіміотерапії може бути ефективним методом, який зменшить когорту неоперабельних хворих із білобарним метастатичним ураженням печінки із задовільним онкологічним ефектом.
\end{abstract}

Ключові слова: паренхімозберігаюча хірургія печінки; $R 1$ vascular detechmant; край резекції; метастази колоректального раку; важкодоступні сайти печінки.

\section{ВСТУП}

Дискусія щодо доцільності виконання широкого відступу від краю пухлинного вогнища при резекціях печінки у пацієнтів з метастазами колоректального раку (мКРР) триває майже 20 років. Тактика відступу $\geqslant 1$ см обгрунтована результатами аналізу декількох провідних центрів, у яких прогнозували достовірно гіршу виживаність серед пацієнтів у разі меншого відступу від краю пухлини [1]. Група хірургів на чолі з М. I. D’Angelica започаткували вищеописану тактику, і впродовж останніх 10 років продовжують публікувати матеріали на підтвердження доцільності широкого відступу від краю метастатичного вогнища, наголошуючи, що відступ в 1 см дозволяе покращити віддалені результати лікування [2]

Майже одночасно низка спеціалізованих хірургічних центрів почали відстоювати хірургічну практику, яка передбачала відступ 1 мм. Нещодавно ці самі автори опублікували дані, що R1 має нижче прогностичне значення порівняно з біологічними особливостями первинної пухлини та ії метастазів $[3,4]$. Таке різноманіття оприлюднених доказів спонукало до активного пошуку єдино правильного рішення. Варто вказати, що більшість публікацій з результатами резекції множинних метастазів схожі за своїм підходом щодо відступу - спеціалісти стверджують, що використовували мінімальний край відступу з метою максимального збереження паренхіми печінки.

У 2016 р. було доведено, що паренхімозберігаюча хірургія (ПЗХ) правої частки печінки має стати «золотим стандартом» для хворих мКРР, оскільки сам факт її видалення призводить до хронічної печінкової недостатності, зниження якості життя та достовірного зменшення його тривалості [5].
Водночас активно впроваджується тактика одноетапних УЗконтрольованих паренхімозберігаючих резекцій печінки, альтернативної методики при білобарному метастатичному ураженні мКРР, що передбачає паренхімозберігаюче видалення усіх метастатичних вогнищ в печінці за один етап [6]. Такий підхід також вважається адаптованою методикою «cherrypicking surgery», яка використовувалася при видаленні субкапсульних метастазів у печінці [7]. G. Torzilli та співавтори розширили показання до УЗ-контрольованих паренхімозберігаючих резекцій печінки та адаптували цю технологію для видалення глибоко розташованих метастатичних вогнищ у печінці [8,9].

Таким чином, останній консенсус щодо стратегії хірургічного лікування метастазів колоректального раку було опубліковано у 2016 р., у ньому чітко сформульовано, що відступ $\geqslant 1$ мм є достатнім та безпечним [10]. Проте дотепер маловивченими залишаються результати паренхімозберігаючої стратегії при локалізації метастатичних утворень у важкодоступних сайтах печінки (ВСП) з точки зору хірургічної анатомії органа (переважно праве «венозне ядро», портальні та кавальні «ворота» печінки, паракавальна частина першого сегмента).

\section{МАТЕРІАЛИ ТА МЕТОДИ}

Виконано проспективне одноцентрове дослідження (січень 2015 р. - липень 2020 р.), у яке було включено 185 хворих на мКРP (pT1-4N0-2M0-1) (рис. 1).

Це дослідження зареєстровано в міжнародній базі (www.researchregistry.com/browse-the-registry) як «Parenchyma sparing liver surgery in colorectal cancer patients with metastasis in hard to reach anatomic cites». Залежно від локалізації мета- 


\begin{tabular}{|c|c|}
\hline \multicolumn{2}{|c|}{ Хворі на мКРP (рT1-4N0-2M0-1) } \\
\hline \multicolumn{2}{|c|}{$\downarrow$} \\
\hline \multicolumn{2}{|c|}{ Паренхімозберігаюча хірургія печінки } \\
\hline \multicolumn{2}{|c|}{$v$} \\
\hline $\begin{array}{c}\text { Периферично } \\
\text { локалізовані метастази } \\
\text { (ПлМ) } \\
\text { Анатомічні сайти: } \\
\text { S1(Спігелієва частка), S2, } \\
\text { S3, S6, S7 }\end{array}$ & $\begin{array}{c}\text { Центральні сайти печінки } \\
\text { (ЦСП) } \\
\text { Анатомічні сайти: } \\
\text { S1(паракавальна та } \\
\text { каудальна частка), } \\
\text { портальні/кавальні } \\
\text { «ворота», «глибокі» сайти } \\
\text { S4, S5, S8 }\end{array}$ \\
\hline \multicolumn{2}{|c|}{$\vee$} \\
\hline $\begin{array}{r}\text { Первинні точки дослідже } \\
\text { безрецидив }\end{array}$ & $\begin{array}{l}\text { ня: загальна виживаність, } \\
\text { виживаність }\end{array}$ \\
\hline
\end{tabular}

Рис. 1. Дизайн дослідження

статичних вогнищ мКРР хворих було розподілено на 2 групи порівняння. До першої групи $(\mathrm{n}=107)$ віднесли хворих, які мали периферично локалізовані метастази (ПЛМ) у паренхімі лівої латеральної секції (S2, S3), задньої секції (S6, S7), Спігелієвій частці S1 та субкапсульно на глибині 1-2 см. До другої групи $(\mathrm{n}=78)$ віднесли хворих з ураженням центральних сайтів печінки (ЦСП), метастатичні вогнища в яких локалізовані переважно в межах «правого венозного ядра» печінки, портальних та кавальних воріт, паракавальної та каудальної частини $\mathrm{S} 1$, глибоких сайтах S4, S5, S8.

Критерії включення: хворі на мКРР $3 \geqslant 1$ метастатичним вогнищем в печінці, що мають перспективу резекції (можливість збереження $\geqslant 30 \%$ паренхіми печінки). Критерії виключення передбачали наявність у хворих $>3$ метастазів у легені та/чи перитонеальний карциноматоз. Первинні точки дослідження включали безпосередні хірургічні результати, загальну та безрецидивну виживаність. Контроль локального прогресування здійснювали за допомогою проведення комп'ютерної томографії (КТ) кожні 4 міс 3 моменту операції. Віддалені результати оцінювали за показником загальної виживаності (з моменту завершення хірургічного лікування) та тривалістю періоду до прогресування хвороби (безрецидивна виживаність). Хірургічна техніка включала принципи «crash-clamping» 3 шириною відступу від краю метастатичної тканини $\geqslant 1$ мм. У разі контакту метастазу з судинними структурами печінки

Таблиця 1. Характеристика хірургії та поширення пухлинного процесу, \%

\begin{tabular}{|c|c|c|c|}
\hline Показник & $\begin{array}{c}\text { ЦСП } \\
(n=78)\end{array}$ & ПЛМ (n=107) & $\mathbf{p}$ \\
\hline Кількість видалених метастатичних вогнищ, медіана (мінімум; максимум) & $6(1 ; 16)$ & $7(2 ; 19)$ & 0,16 \\
\hline \multicolumn{4}{|l|}{ Розподіл хворих за кількістю метастазів: } \\
\hline 1 & $10(12,8)$ & $14(13,1)$ & 0,95 \\
\hline $2-5$ & $24(30,7)$ & $51(47,6)$ & 0,02 \\
\hline $6-10$ & $19(24,4)$ & $16(14,9)$ & 0,1 \\
\hline $11-15$ & $23(29,5)$ & $21(19,6)$ & 0,2 \\
\hline$\geqslant 15$ & $2(2,5)$ & $5(4,6)$ & 0,46 \\
\hline Білобарне метастатичне ураження печінки & $29(37,2)$ & $31(28,9)$ & 0,24 \\
\hline Синхронний статус метастатичного ураження & $39(50)$ & $64(59,8)$ & 0,18 \\
\hline Одномоментна (синхронна) хірургія первинної пухлини та резекція печінки & $14(17,9)$ & $19(17,7)$ & 0,97 \\
\hline Локалізація первинної пухлини (ліва/права половина товстої кишки) & $64(82,1) / 14(17,9)$ & $93(86,9) / 14(13,1)$ & 0,36 \\
\hline Хірургія первинних пухлин: лапароскопічна/відкрита & $57(73,1) / 21(26,9)$ & $78(72,8) / 29(27,1)$ & 0,97 \\
\hline Край резекції R1v & $24(30,7)$ & $6(5,6)$ & 0,001 \\
\hline \multicolumn{4}{|l|}{ Ререзекції печінки: } \\
\hline 1 & $26(33,3)$ & $32(29,9)$ & 0,62 \\
\hline 2 та більше & $7(8,9)$ & $11(10,3)$ & 0,76 \\
\hline «Велика» хірургія печінки & $5(6,4)$ & $14(13,1)$ & 0,14 \\
\hline \multicolumn{4}{|l|}{ Хірургічні доступи: } \\
\hline Верхньо-серединна лапаротомія & $1(1,3)$ & $5(4,6)$ & 0,2 \\
\hline Ј-подібна лапаротомія справа & $68(87,2)$ & $91(85,1)$ & 0,6 \\
\hline Тотальна лапаротомія & $9(11,5)$ & $11(10,2)$ & 0,7 \\
\hline Об'єм видаленої метастатичної тканини (см³), медіана (мінімум; максимум)* & $95(12 ; 236)$ & $127(3 ; 274)$ & 0,1 \\
\hline
\end{tabular}

1-3-го порядку та за відсутності істинної інвазії застосовували тактику «vascular detachment» (R1v). Ішемія включала техніку класичного та селективного маневру Прінгла (20 хв - ішемія та 5 хв - реперфузія). Усі операції супроводжувалися інтраопераційною ультразвуковою навігацією.

Стандартна хірургія раку ободової кишки включала повну мезоколоектомію в межах анатомо-фасціальних ембріональних компартментів та центральне лігування судин ободової кишки (Complete Mesocolic Excision with Central Vascular Ligation). Хірургія раку прямої кишки передбачала обов'язкову тотальну/парціальну мезоректумектомію з урахуванням локалізації пухлини, а об'єм лімфодисекції при раку ободової та прямої кишки був D3. Хіміотерапію та променеву терапію проводили відповідно до останніх рекомендацій Національної загальної онкологічної мережі (National Comprehensive Cancer Network - NCCN) [11].

Ускладнення були зібрані за представленими даними з історій хвороби оперованих хворих. Тяжкими ускладненнями вважали клінічні випадки, коли пацієнти потребували лікування в умовах відділення інтенсивної терапії, додаткової хірургічної (малої/великої) інтервенції, чи призвели до смерті хворого. Ускладнення унаслідок порушення функціонування печінки чи біліарної системи розцінювали як гепатоспецифічні.

Статистичний аналіз. Виживаність розраховували за методом Каплана - Мейєра та logrank-тестом для порівняння показників у групах хворих. Для порівняння кількісних величин у групах за умов параметричного розподілу використовували t-тест. Для розрахунку статистичної достовірності різниці показників використовували метод ANOVA, у тому числі post hoc test та непараметричний тест (U-критерій Манна - Уїтні). Статистично достовірними вважали величини при $\mathrm{p}<0,05$. Величини вимірювали як медіана \pm мінімум та максимум. version 25.0 (IBM, Armonk, New York, USA).

\section{РЕЗУЛЬТАТИ}

185 хворим на мКРР було виконано паренхімозберігаючі резекції печінки. Проведений аналіз розподілу хворих за кількістю видалених метастатичних вогнищ в групах не продемонстрував достовірної відмінності, медіана становила 6 i 7 для ЦСП та ПЛМ відповідно $(\mathrm{p}=0,16)$. Солітарне метастатичне ураження печінки було зареєстровано у $10(12,8 \%)$ хворих групи ЦСП та $14(13,1 \%)$ групи ПЛМ, p=0,95. Було виявлено різницю в когорті хворих, у яких діагностували від 2 до 5 метастатичних вогнищ (30,7 та 47,6\% для групи ЦСП та ПЛМ відповідно), $\mathrm{p}=0,02$. Математичний аналіз продемонстрував однорідність досліджуваних груп у когортах Статистичний аналіз виконували, використовуючи IBM SPSS ${ }^{\circledR}$

*Використовували волюметрію метастатичних вогнищ. 
хворих $з$ діагностованими $\geqslant 6$ метастатичними вогнищами в печінці (табл. 1). При цьому білобарне метастатичне ураження було виявлено у $29(37,2 \%)$ та $31(28,9 \%)$ хворих з груп ЦСП та ПЛМ відповідно ( $\mathrm{p}=0,24)$. Волюметрія метастатичної тканини оперованих хворих також підтвердила однорідність досліджуваних груп, де медіана об’єму метастатичної тканини становила $95 \mathrm{~cm}^{3}$ в групі ЦСП та $127 \mathrm{~cm}^{3}-$ у групі ПЛМ, p=0,1. У половини хворих групи ЦСП метастатичне ураження мало синхронний характер, тоді як у хворих із групи ПЛМ цей показник становив 59,8\%. Лівобічно локалізовані первинні пухлини склали більшість та були представлені в $64(82,1 \%)$ та $93(86,9 \%)$ випадках для ЦСП та ПЛМ груп відповідно $(\mathrm{p}=0,36)$. Хірургія первинних пухлин мКРР здійснювалася лапароскопічно у 73,1 та $72,8 \%$ випадків для хворих із груп ЦСП та ПЛМ відповідно. Одномоментно первинну пухлину та метастази в печінці видаляли у $14(17,9 \%)$ випадках у групі ЦСП та $19(17,7 \%)$ - для хворих із ПЛМ, p=0,97. 3 приводу первинних пухлин мКРР, $145(78,4 \%)$ хворих були оперовані в умовах відділення онкоколопроктології Національного інституту раку.

У цілому у 141 хворого було зареєстровано прогресування хвороби з повторним метастатичним ураженням печінки та $76(53,9 \%)$ з них отримали ререзекцію. Зокрема, у $26(33,3 \%)$ та $32(29,9 \%)$ хворих груп ЦСП та ПЛМ відповідно була виконана 1 ререзекція печінки ( $\mathrm{p}=0,62)$. Із когорти хворих, яким проведено 1 ререзекцію, було зареєстровано прогресування хвороби у $55(72,4 \%)$ випадках та тільки $18(32,7 \%)$ з них отримали 2-гу та більше ререзекцій печінки. Так, у групі ЦСП 2 та більше ререзекцій здійснили у $7(8,9 \%)$ випадках, тоді як у ПЛМ - в $11(10,3 \%), \mathrm{p}=0,76$.

J-подібну лапаротомію справа застосовували в обох групах найчастіше (ЦСП - 87,2\% та ПЛМ - 85,1\%), p=0,28. Принцип ПЗХ резекцій у групі ЦСП корелював з частішим застосуванням принципу R1v detachment. Такий принцип було імплементовано у $24(30,7 \%)$ випадках при центрально локалізованих метастазах та в $6(5,6 \%)$ випадках групи ПЛМ ( $\mathrm{p}=0,001)$. Тривалість операції не залежала від переважної локалізації метастатичних вогнищ мКРР, медіана якої становила 306 хв та 285 хв відповідно для ЦСП та ПЛМ груп $(\mathrm{p}=0,08)$. «Великі» резекції печінки (видалення $\geqslant 3$ анатомічних сегментів печінки) виконали у $5(6,4 \%)$ та $14(13,1 \%)$ випадках для групи ЦСП та ПЛМ відповідно (p=0,14).

Післяопераційні тяжкі ускладнення зареєстровано у $19(24,4 \%)$ та $17(21,8 \%)$ хворих для груп ЦСП та ПЛМ відповідно, $\mathrm{p}=0,15$ (табл. 2). Не зареєстровано відмінностей у групах за частотою гепатоспецифічних ускладнень, що становила 8,9 та 4,6\% для груп ЦСП та ПЛМ відповідно $(p=0,3)$. У групі 3 центрально локалізованими метастазами гостра печінкова недостатність (ГПН) не перевищувала ступеня А та була виявлена у $5(6,4 \%)$ пацієнтів. У групі ПЛМ показники ГПН ступенів А та В було виявлено у 8 (7,5\%) та $1(0,9 \%)$ випадках відповідно. Серед тяжких гепатоспецифічних ускладнень найчастіше реєстрували жовчну норицю та білому. Медіана загальної тривалості теплової ішемії під час транссекції паренхіми печінки була значно вищою у групі ЦСП $-39 \pm 25,8$ хв порівняно 3 групою ПЛМ $-15 \pm 18,05$ хв (p<0,001). Центральні ПЗХ резекції не асоціювалися з більшою крововтратою чи показником периопераційної гемотрансфузії (див. табл. 2). Цікаво також, що випадок 30-денної післяопераційної смертності був зареєстрований тільки у хворих групи ЦСП та становив 1,3\%, що було спричинено мезентеріальним тромбозом на 5-ту післяопераційну добу. Рівень 90-денної смертності становив 1,3 та 0,9\% для хворих групи ЦСП та ПЛМ відповідно.

На рис. 2а графічно представлено рівні кумулятивної загальної виживаності у групах дослідження $(\mathrm{n}=185)$. Показники загальної 3-річної виживаності становили $74 \%$ та $66 \%$ для груп ЦСП та ПЛМ відповідно, p=0,3. Кумулятивна 3-річна виживаність для усіх включених у дослідження 185 хворих склала $68 \%$. Вище вже згадувалося, що хірургічний принцип R1v використали у когорті 24 хворих із групи ЦСП і тільки у 6 хворих групи ПЛМ. Саме тому ми демонструємо виживаність для групи ЦСП, використовуючи статус краю резекції як стратифікаційну змінну. На рис. 26 представлено криві кумулятивної 3-річної виживаності для когорт R0 та R1v, що становила 73 та $48 \%$ відповідно $(\mathrm{p}=0,44)$ (рис. $3 \mathrm{a})$.

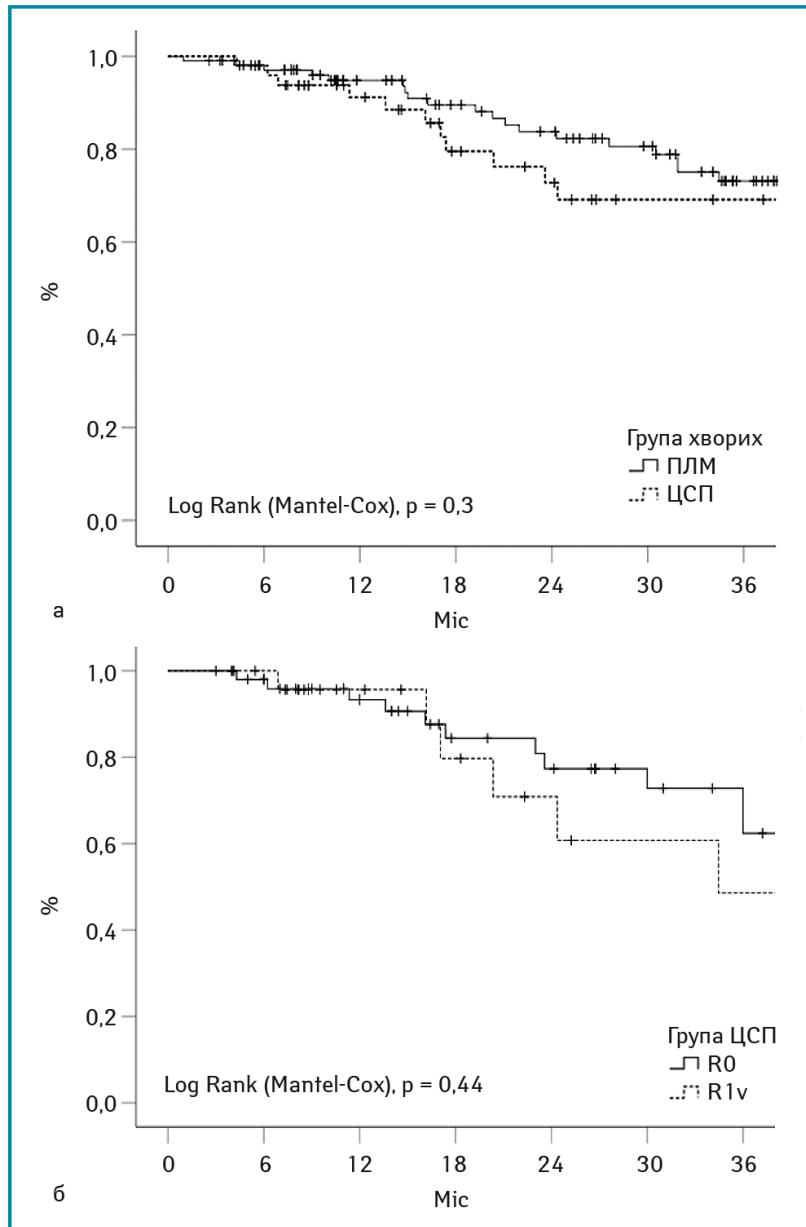

Рис. 2. Загальна кумулятивна виживаність: а - оцінка за методом Каплана - Мейєра загальної кумулятивної виживаності для 185 хворих на мКРР групи ЦСП та ПЛМ; б - оцінка за методом Каплана - Мейєра загальної кумулятивної виживаності у 78 хворих на мКРР групи ЦСП, стратифікована для когорт R0 та R1v

Таблиця 2. Операційні та периопераційні дані, \%

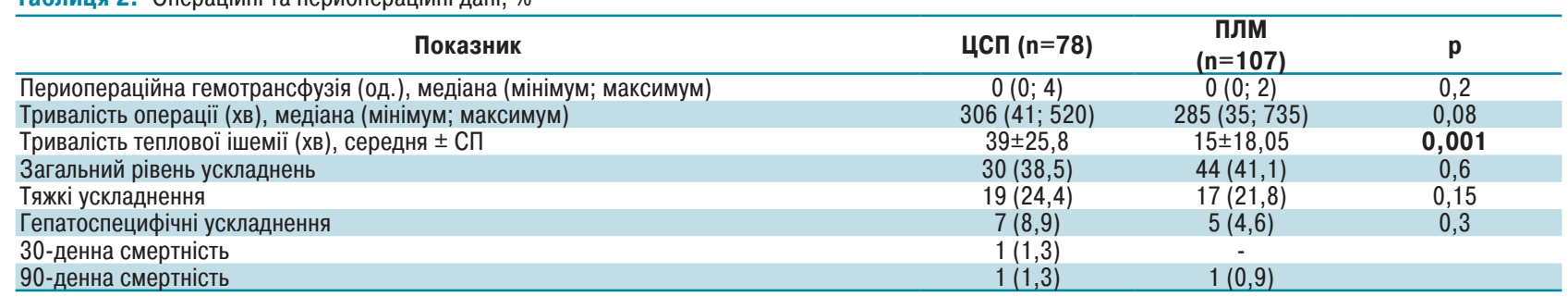




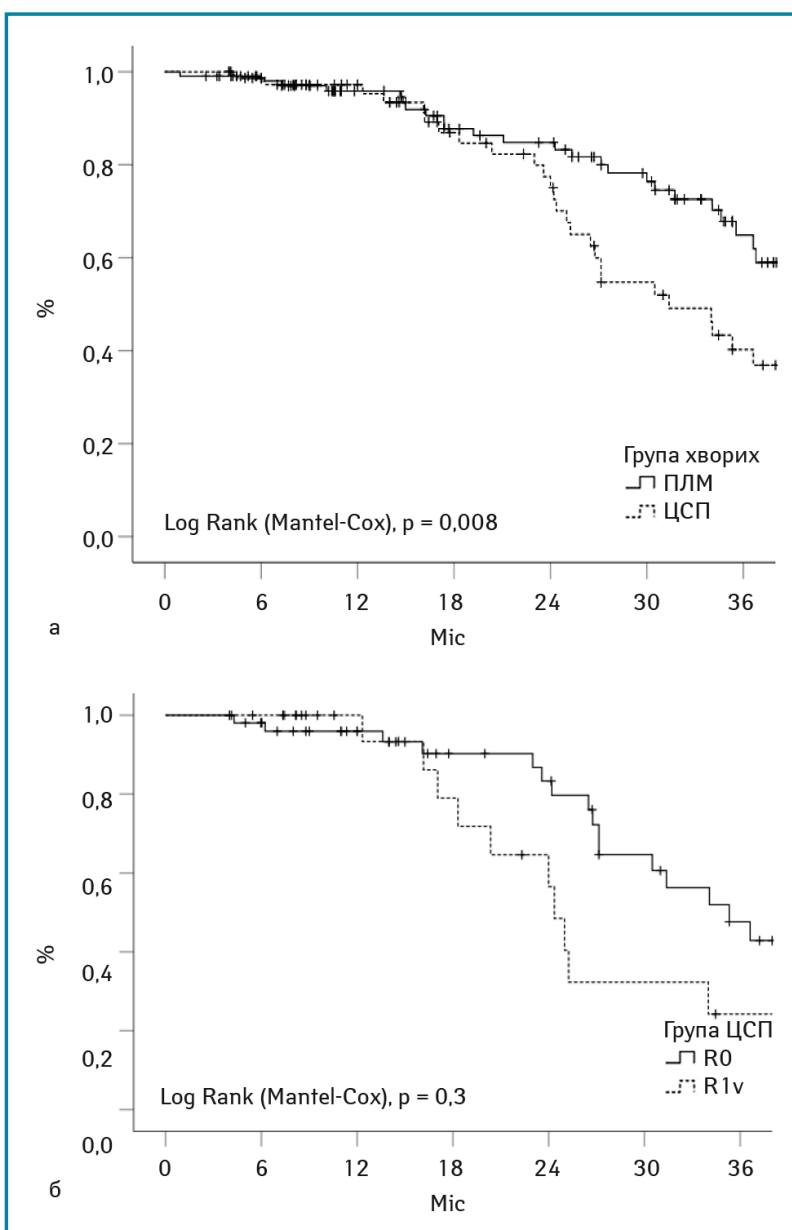

Рис. 3. Безрецидивна кумулятивна виживаність: a - оцінка за методом Каплана - Мейєра безрецидивної кумулятивної виживаності для 185 хворих мКРР у групах порівняння ПлМ та ЦСП; б - оцінка за методом Каплана - Мейєра безрецидивної кумулятивної виживаності для 78 хворих мКРР групи ЦСП, стратифікована за статусом краю резекції (R0/R1v)

Була зареєстрована статистична відмінність за рівнем 3-річної безрецидивної виживаності у досліджуваних групах хворих, яка становила 63 і 41\% відповідно для групи ЦСП та ПЛМ $(\mathrm{p}=0,008)$. Безрецидивна кумулятивна 3-річна виживаність для когорт R0 та R1v хворих групи ЦСП становила 43 та $33 \%$ відповідно $(\mathrm{p}=0,44)$ (рис. 36$)$.

\section{ОБГОВОРЕННЯ}

Незважаючи на стрімкий розвиток системної хіміотерапії, видалення первинної пухлини та всіх сайтів уражених віддаленими метастазами залишається пріоритетним у показниках виживаності таких хворих. Більш ніж у 50\% пацієнтів з мКРР з резекцією печінки в анамнезі з приводу іiі метастатичного ураження відмічають ризик повторного метастатичного ураження органа, що, у свою чергу, потребує лікування 2-ю лінією хіміопрепаратів і ререзекції. Принцип широкого краю відступу (1 см) при резекціях мКРР в печінці змушував хірургів виконувати «великі» та розширені гепатектоміі. Така тактика здебільшого призводить до високого рівня тяжких ускладнень, зокрема гострої печінкової недостатності в ранній післяопераційний період та синдрому малої печінки у пізніших термінах, що виникає, за різними даними, в 4-16\% випадків [12]. Отже, хірургічна стратегія безпосередньо впливає на можливість адекватного системного лікування таких пацієтів в ад'ювантному режимі. Крім того, застосування великих резекцій супроводжується ризиком виконання R1 у $30 \%$, за да- ними останніх метааналізів [13]. Тому ми вважаємо, що ПЗХ, у поєднанні з інтраопераційною УЗ-навігацією, орієнтування в 3D-анатомії судинних структур 1-3-го порядку та застосування R1v vascular detachment підвищують шанси кожного хворого при отриманні повторного хірургічного лікування.

3 нашої точки зору, ПЗХ є альтернативою у разі центрально локалізованих метастатичних вогнищ (у межах портальних чи кавальних воріт печінки). За класичного хірургічного алгортиму дотримання широкого краю відступу від тканини метастатичного вогнища, що контактує, проте немає ознак істинного вростання в стінку устя глісонових структур першого чи другого порядку, а також устя головних печінкових вен, незворотно змушує хірургів виконувати «великі» резекції печінки. Така тактика достовірно підвищує ризики гострої печінкової недостатності, оскільки «small future liver remnant volume» - головна причина смертності хворих при резекціях печінки. Тоді як штучна стимуляція гіпертрофії (емболізація чи лігування портальної вени) несуть у собі приховані ризики пасивної стимуляції росту дисемінованих мікрометастазів («minimal residual disease») [14]. Свідчення на користь можливої ініціації неконтрольованого пухлинного росту на фоні процесів хронічного запалення чи штучної активації механізмів гіпертрофії почали публікувати ще з 80 -х років $\mathrm{XX}$ ст. та дотепер активно вивчаються як в умовах експерименту, так і в клініці (трансплантологія) [15].

Отримані нами результати виживаності демонструють референтні світовим значення для хворих як із центрально розташованими метастатичними вогнищами, так і з периферичною локалізацією. Крім того, застосована хірургічна тактика не призвела до підвищення рівня післяопераційних ускладнень чи смертності, незважаючи на свою технічну складність. У групі центральних резекцій була зареєстрована більш довготривала ішемія внаслідок використання маневру Прінгла та частіше виконувалася гемотрансфузія.

Стандартною хірургічною стратегією при білобарному метастатичному ураженні печінки мКРР вважається двоетапна резекція печінки (ДЕР), що включає атипове видалення вогнищ у більш перспективній частці печінки (зазвичай це ліва частка), емболізацію портальної вени (ЕПВ), хіміотерапію та наступну гемігепатектомію справа другим хірургічним етапом [16]. Основним недоліком ДЕР вважають незавершення (drop-out) 2-го хірургічного етапу внаслідок прогресування хвороби чи недостатньої гіпертрофії паренхіми [17]. Автори пояснюють необхідність виконання атипових резекцій 1-м етапом із перспективної частки печінки способом попередження неконтрольованого пухлинного росту за умов штучного стимулювання гіпертрофії печінки [18]. Доведено, що метастатичні вогнища мікроскопічного розміру (мікрометастази), які не були зареєстровані на КТ/магнітно резонансній томографії, потенційно знаходяться у неемболізованій частці печінки та можуть візуалізуватися після виконання ЕПВ внаслідок потенціювання їхнього росту штучно створеним мікрооточенням стимуляції поділу клітинних елементів паренхіми печінки [19]. N. Kokudo та співавтори у власному дослідженні показали, що індекс проліферації клітин аденокарциноми мКРР збільшується на фоні виконання ЕПВ [20]. Середній об'єм метастатичної тканини в печінці був достовірно більшим на 20,8\% у групі хворих, які отримували процедуру ЕВП, автори виконували волюметрію через 3 тиж після емболізації. Більше того, у групі без ЕПВ за період спостереження не було зареєстровано достовірної відмінності за об'ємом метастатичної тканини. У 2012 р. була запропонована альтернативна техніка ALPPS резекцій печінки у хворих, випадки метастатичиного ураження печінки у яких вважали нерезектабельними [21]. Однак деякі клінічні дослідження продемонстрували вищу частоту рецидиву хвороби в оперованій культі печінки після ALPPS порівняно з ДЕР (8 із 8 порівняно з 9 із 17 хворих відповідно, $\mathrm{p}=0,005)$ [22]. Тому онкологічний ефект від ALPPS залишається маловивченим через відсутність рандомізованих досліджень $з$ даної проблеми. 
Новітня модель пухлинного росту та поширення клітин пухлини на ранніх стадіях хвороби демонструє, що всі метастази мають статус синхронних, оскільки виникають одночасно 3 первинною пухлиною. Тоді як клінічне виявлення метахронних метастазів пояснюється ефектом порушення імунного виживання та «сплячим» статусом мікрометастазів, що наявні вже на ранніх стадіях колоректального раку [23]. Дифузія мікрометастазів та «сплячий» стан клітин мКРР на сьогодні є основним аргументом проти виконання широкого краю резекції та/чи великої анатомічно орієнтованої хірургії печінки для таких хворих. Саме тому ми віримо в те, що тактика ПЗХ у поєднанні $з$ інтраопераційною ультразвуковою навігацією $€$ найкращою хірургічною стратегією для хворих з метастатичним ураженням важкодоступних сайтів печінки.

Як уже було сказано раніше, тільки повне хірургічне видалення метастазів мКРР в печінці дозволяє подовжити тривалість життя таких хворих. Метою даного дослідження було вивчення хірургічної та онкологічної ефективності ПЗХ та R1v vascular detachment у хворих з метастазами в ЦСП. Отримані результати підтвердили, що адаптація ПЗХ до видалення метастазів у групі ВСП не призвела до підвищення частоти тяжких гепатоспецифічних післяопераційних ускладнень. Однак у групі ВСП була зареєстрована більш довготривала теплова ішемія під час використання обмеження притоку крові маневром Прінгла. Загалом встановлено, що серед всіх включених хворих більше половини з повторним метастатичним ураженням оперованої печінки змогли отримати 1 ререзекцію та 18 хворих отримали $\geqslant 2$ ререзекцій. Онкологічні результати в рамках даного дослідження перебувають на рівні світових референтних даних. Незважаючи на той факт, що у третини хворих у групах ЦСП та ПЛМ відмічали білобарне метастатичне ураження, рівень безрецидивної 3-річної виживаності становив 41 та 63\% відповідно. Когорта хворих у групі ЦСП, які мали статус краю резекції R1v, продемонструвала $33 \%$ рівень 3-річної безрецидивної виживаності. Водночас нещодавно опубліковані клінічні дослідження 3 порівняння ефективності ДЕР та T-ALPPS показали 3-річну безрецидивну виживаність 9,5 та 11,1\% відповідно [24].

\section{ВИСНОВКИ}

Доведено, що використання ПЗХ в рамках мультикомпонентної стратегії $є$ безпечним та ефективним з онкологічної точки зору для хворих з колоректальним раком та білобарним метастатичним ураженням печінки. Принцип ПЗХ дозволяе адекватно видаляти навіть «глибоко» розташовані метастатичні вогнища із збереженням функції органа та підвищуе імовірність виконання ререзекції печінки у разі прогресування основного захворювання. Адаптація паренхімозберігаючої хірургічної стратегії у хворих з метастатичним ураженням важкодоступних сайтів печінки забезпечила референтну 3-річну безрецидивну виживаність на рівні світового досвіду. Стратегія $\mathrm{R} 1 \mathrm{v}$ у поєднанні із сучасними схемами поліхіміотерапії може бути ефективним методом, який зменшить когорту неоперабельних хворих з білобарним метастатичним ураженням печінки із задовільним онкологічним ефектом.

\section{СПИСОК ВИКОРИСТАНОЇ ЛІТЕРАТУРИ}

1. Pawlik, T. M., Scoggins, C. R., Zorzi, D., Abdalla, E. K., Andres, A., Eng, C., Vauthey, J. N. (2005). Effect of surgical margin status on survival and site of recurrence after hepatic resection for colorectal metastases. Annals of Surgery, 241(5), 715-724. doi: 10.1097/01.sla.0000160703.75808.7d

2. D'Angelica M. I. (2017). Positive Margins After Resection of Metastatic Colorectal Cancer in the Liver: Back to the Drawing Board? Annals of Surgery Oncology, 24(9), 2432-2433. doi: 10.1245/s10434-017-5908-1.

3. Sadot, E., Koerkamp, B. G., Leal, J. N., Shia, J., Gonen, M., Allen, P. J., D'Angelica, M. I. (2015). Resection margin and survival in 2368 patients undergoing hepatic resection for metastatic colorectal cancer: surgical technique or biological surrogate? Annals of Surgery, 262(3), 476-485. doi: 10.1097/SLA.0000000000001427.

4. Wang, J., Margonis, G. A. Amini, N., Andreatos, N., Yuan, C., Damaskos, C. Weiss, M. J. (2018). The Prognostic Value of Varying Definitions of Positive Resection Margin in Patients with Colorectal Cancer Liver Metastases. Journal of Gastrointestinal Surgery, 22(8), 1350-1357. doi: 10.1007/s11605-018-3748-3.

5. Alvarez, F. A., Sanchez Claria, R., Oggero, S., \& de Santibañes, E. (2016) Parenchymal-sparing liver surgery in patients with colorectal carcinoma liver metastases. World Journal of Gastrointestinal Surgery, 8(6), 407-423. doi: 10.4240/wjgs.v8.i6.407.

6. Torzilli, G., Serenari, M., Viganò, L., Cimino, M., Benini, C., Massani, M., Jovine, E. (2019). Outcomes of enhanced one-stage ultrasound-guided hepatectomy for bilobar colorectal liver metastases compared to those of ALPPS: a multicenter casematch analysis. HPB (Oxford), 21(10), 1411-1418. doi: 10.1016/j.hpb.2019.04.001. 7. Krausch, M., Raffel, A., Anlauf, M., Schott, M., Lehwald, N., Krieg, A., ... Knoefel, W. T. (2014). "Cherry picking", a multiple non-anatomic liver resection technique, as a promising option for diffuse liver metastases in patients with neuroendocrine tumours. World Journal of Surgery, 38(2),392-401. doi: 10.1007/s00268-013-2267-3.

8. Torzilli, G., \& Cimino, M. M. (2017). Extending the Limits of Resection for Colorectal Liver Metastases Enhanced One Stage Surgery. Journal of Gastrointestinal Surgery, 21(1), 187-189. doi: 10.1007/s11605-016-3250-8.

9. Burlaka, A. A., \& Kolesnik, O. O. (2020). Parenchyma sparing multicomponent liver resection strategy for multiple bilobar synchronous colorectal cancer metastasis. Clinical Case Reports, 8(4), 661-666. doi: 10.1002/ccr3.2742.

10. Adam, R., de Gramont, A., Figueras, J., Kokudo, N., Kunstlinger, F., Loyer, E., ... Påhlman, L. (2015). Managing synchronous liver metastases from colorectal cancer: a multidisciplinary international consensus. Cancer Treatment Reviews, 41(9), 729-741. doi: 10.1016/j.ctrv.2015.06.006.

11. National Comprehensive Cancer Network. (2020). Colon cancer(version4.2020). Retrievedfromhttps://www.nccn.org/professionals/physician gls/pdf/colon_blocks.pdf.

12. Narita, M., Oussoultzoglou, E., Bachellier, P., Jaeck, D., \& Uemoto, S. (2015). Post-hepatectomy liver failure in patients with colorectal liver metastases. Surgery Today, 45(10), 1218-1226. doi: 10.1007/s00595-015-1113-7.

13. Viganò, L., Costa, G., Cimino, M. M., Procopio, F., Donadon, M., Del Fabbro, D., ... Torzilli, G. (2018). R1 Resection for Colorectal Liver Metastases: a Survey Questioning Surgeons about Its Incidence, Clinical Impact, and Management. Journal of Gastrointestinal Surgery, 22(10),1752-1763. doi: 10.1007/s11605-018-3820-z.

14. Hoekstra, L. T., van Lienden, K. P., Verheij, J., van der Loos, C. M., Heger, M., \& van Gulik, T. M. (2013). Enhanced tumor growth after portal vein embolization in a rabbit tumor model. Journal of Surgical Research, 180(1), 89-96. doi: 10.1016/j.jss.2012.10.032.

15. Landskron, G., De la Fuente, M., Thuwajit, P., Thuwajit, C., \& Hermoso, M. A. (2014). Chronic inflammation and cytokines in the tumor microenvironment. Journal of Immunology Research, 2014, 149185. doi: 10.1155/2014/149185.

16. Moris, D., Ronnekleiv-Kelly, S., Kostakis, I. D., Tsilimigras, D. I., Beal, E. W., Papalampros, A., ... Pawlik, T. M. (2018). Operative Results and Oncologic Outcomes of Associating Liver Partition and Portal Vein Ligation for Staged Hepatectomy (ALPPS) Versus Two-Stage Hepatectomy (TSH) in Patients with Unresectable Colorectal Liver Metastases: A Systematic Review and Meta-Analysis. World Journal of Surgery, 42(3), 806-815. doi: 10.1007/s00268-017-4181-6

17. Viganò, L., Torzilli, G., Cimino, M., Imai, K., Vibert, E., Donadon, M., ... Adam, R. (2016). Drop-out between the two liver resections of two-stage hepatectomy. Patient selection or loss of chance? European Journal of Surgical Oncology, 42(9), 1385-1393. doi: 10.1016/j.ejso.2016.03.020.

18. Jaeck, D., Oussoultzoglou, E., Rosso, E., Greget, M., Weber, J. C., Bachellier, P. (2004). A two-stage hepatectomy procedure combined with portal vein embolization to achieve curative resection for initially unresectable multiple and bilobar colorectal liver metastases. Annals of Surgery, 240, 1037-1049. doi: 10.1097/01.sla.0000145965.86383.89.

19. de Graaf, W., van den Esschert, J.W., van Lienden, K. P., \& van Gulik, T. M. (2009). Induction of tumor growth after preoperative portal vein embolization: is it a real problem? Annals of Surgery Oncology, 16(2), 423-430. doi: 10.1245/s10434-008-0222-6.

20. Kokudo, N., Tada, K., Seki, M., Ohta, H., Azekura, K., Ueno, M.

Kato, Y. (2001). Proliferative activity of intrahepatic colorectal metastases after preoperative hemihepatic portal vein embolization. Hepatology, 34, 267-272. doi: 10.1053 /jhep.2001.26513

21. Schnitzbauer, A. A., Lang, S. A., Goessmann, H., Nadalin, S., Baumgart, J., Farkas, S. A., ... Schlitt H. J. (2012). Right portal vein ligation combined with in situ splitting induces rapid left lateral liver lobe hypertrophy enabling 2-staged extended right hepatic resection in small-for-size settings. Annals of Surgery, 255, 405-414. doi: 10.1097/SLA.0b013e31824856f5.

22. Adam, R., Imai, K., Castro Benitez, C., Allard, M. A., Vibert, E., Sa Cunha, A., Castaing, D. (2016). Outcome after associating liver partition and portal vein ligation for staged hepatectomy and conventional two-stage hepatectomy for colorectal liver metastases. British Journal of Surgery, 103(11),1521-1529. doi: 10.1002/bjs. 10256.

23. Aguirre-Ghiso, J. A. (2007). Models, mechanisms and clinical evidence for cancer dormancy. Nature Reviews Cancer, 7(11), 34-846. doi: 10.1038/nrc2256.

24. Robles-Campos, R., Brusadin, R., López-Conesa A., López-López, V., Navarro-Barrios, Á., López-Espín, J. J., ... Parrilla, P. (2019). Long-Term Outcome After Conventional Two-Stage Hepatectomy Versus Tourniquet-ALPPS in Colorectal Liver Metastases: A Propensity Score Matching Analysis. World Journal of Surgery, 43(9), 2281-2289. doi: 10.1007/s00268-019-05031-w.

\section{Паренхимосохраняющая стратегия при метастатическом поражении печени: когортное проспективное исследование}

А.А. Бурлака

Национальный институт рака, Киев, Украина

Актуальность. Дискуссия о целесообразности выполнения широкого отступа от края опухолевого очага при резекции печени у пациентов с метастазами колоректального рака (мКРР) продолжается почти 20 лет. Однако до сих пор малоизученными остаются результаты паренхимосохраняющей стратегии при локализации метастатических образований в труднодоступных сайтах печени с точки зрения хирургической анатомии органа (преимущественно правое «венозное ядро», портальные и кавальные «ворота» печени, паракавальные части первого сегмента). Материалы и методы. Выполнено проспективное одноцентровое исследование (январь 2015 г. - июль 2020 г.) с включением 185 больных мКРР (pТ14N0-2M0-1). В зависимости от локализации метастатических очагов мКРР больные были разделены на 2 группы сравнения. K первой группе $(n=107)$ отнесли пациентов с периферично 


\section{Оригінальні статті / Original Articles}

локализованными метастазами (ПЛМ), в паренхиме левой латеральной секции (S2, S3), задней секции (S6, S7), Спигелиевой доли S1 и субкапсульно на глубине 1-2 см. Ко второй группе $(n=78)$ отнесли больных с поражением центральных сайтов печени (ЦСП), метастатические очаги в которых локализованы преимущественно в пределах «правого венозного ядра» печени, портальных и кавальных ворот, паракавальной и каудальной части S1, глубоких сайтах S4, S5, S8. Результаты. Послеоперационные тяжелые осложнения зарегистрированы у $19(24,4 \%)$ и $17(21,8 \%)$ больных соответственно для групп сравнения, $\mathrm{p}=0,15$. Не было зарегистрировано различий в группах по уровню гепатоспецифичних осложнений, они составляли 8,9 и 4,6\% для ЦСП и ПЛМ соответственно $(p=0,3)$. Было зарегистрировано статистическое отличие по уровню 3-летней безрецидивной выживаемости в исследуемых группах больных, она составила 63 и 41\% соответственно для групп ЦСП и ПЛМ (p=0,008). Кумулятивная безрецидивная 3-летняя выживаемость для когорт R0 и R1v больных группы ЦСП составляла 43 и 33\% соответственно (p = 0,44). Выводы. Адаптация паренхимосохраняющей хирургической стратегии у больных с метастатическим поражением труднодоступных сайтов печени обеспечила референтную 3-летнюю выживаемость, согласно мировому опыту. Стратегия Rlv в сочетании с современными схемами полихимиотерапии может быть эффективным методом, который уменышит когорту неоперабельных больных с билобарным метастатическим поражением печени с удовлетворительным онкологическим эффектом.

Ключевые слова: паренхимосохраняющая хирургия печени; R1 vascular; край резекции; метастазы колоректального рака; труднодоступные сайты печени.

\section{Parenchymal sparing surgery for colorectal cancer liver metastases: cohort prospective study}

Burlaka A.A.

National Cancer Institute, Kyiv

Background. The debate over the surgical strategy optimization in colorectal cancer patients with liver metastases (mCRC) has been ongoing in the last 20 years. However, parenchyma sparing surgery (PPS) in cases of hard to reach liver cites (HTRLC) remain to be controversial. Methods. A prospective analysis of $185 \mathrm{mCRC}$ patients performed who were devided in two groups depending by predominant liver cite localization. Peripherally localized metastases (PLM) $(n=107)($ S2, S3, S6, S7, Spiegel lobe and subcapsular area 1-2 cm below the liver surface). Group 2 included those with metastases localized in HTRLC $(n=78)-$ metastatic lesions of the «right venous core», portal and caval hilum, paracaval part of $\mathrm{S} 1$, «deep» parenchyma cites of S5, S8 and S4. Results. Postoperative major morbidity was $24,4 \%, 21,8 \%(\mathrm{p}=0,15)$ and mortality $8,9 \%, 4,6 \%$ for HTRLC and PLM groups, respectively. R1v principles were implemented in $24(30,7 \%)$ cases with centrally located metastases and in only 6 cases $(5.6 \%)$ with peripheral localized metastases $(p=0,001)$. Cumulative 3-year disease-free survival (DSF) for PLM and HTRLC groups was $63 \%$ and $41 \%(\mathrm{p}=0,008)$. DFS for R1v $(\mathrm{n}=24)$ and R0 (54) cohorts in HTRLC group was $33 \%$ and $43 \%$, respectively $(\mathrm{p}=0,44)$. Conclusions. Principles of the PPS tactic provides an adequate removal of metastatic lesions in hard to reach liver cites allowing to maintain organ functions and increases the feasibility of the repeated liver resections in case of the initial disease progression.

Key words: Parenchymal sparing liver surgery; R1 vascular; resection margin; colorectal cancer liver metastases; hard to reach liver cites.

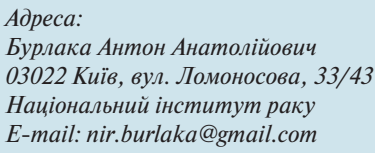

